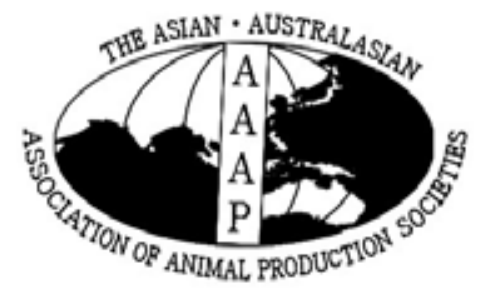

Asian-Aust. J. Anim. Sci.

Vol. 20, No. 2 : 153 - 159

February 2007

www.ajas.info

\title{
Expression of B Cell Activating Factor Pathway Genes in Mouse Mammary Gland
}

\author{
S. Choi, D. J. Jung, J. J. Bong and M. Baik* \\ Major in Molecular Biotechnology, Biotechnology Research Institute, Inst. of Ag. Sci. and Tech. \\ Chonnam National University, Gwangju 500-757, Korea
}

\begin{abstract}
In our previous study, overexpression of extracellular proteinase inhibitor (Expi) gene accelerated apoptosis of mammary epithelial cells, and induced expression of B cell activating factor (BAFF) gene. In this study, we found induction of BAFFreceptor (BAFF-R) gene expression in the Expi-transfected cells. A proliferation-inducing ligand (APRIL) gene is another TNF family member and the closest known relative of BAFF. We found induction of APRIL gene expression in the Expi-overexpressed apoptotic cells. NF- $\mathrm{BB}$ gene was also induced in the Expi-overexpressed cells. Expression patterns of BAFF and APRIL pathway-related genes were examined in in vivo mouse mammary gland at various reproductive stages. Expression levels of BAFF gene were very low at early pregnancy, increased from mid-pregnancy, and peaked at lactation, and thereafter decreased at involution stages of mammary gland. Expression of BAFF-R gene was highly induced in involution stages compared to lactation stages. Thus, expression patterns of BAFF-R gene were correlated to apoptotic status of mammary gland: active apoptosis of mammary epithelial cells occurs at involution stage of mammary gland. Expression levels of NF- $\mathrm{kB}$ gene were higher in involution stages compared to lactation stages. We analyzed mRNA levels of bcl-2 family genes from different stages of mammary development. Bcl-2 gene expression was relatively constant during lactation and involution stages. There was a slight increase in bcl-xL gene expression in involution stages compared to lactation state. Bax gene expression was highly induced in involution stage. Our results suggest that signaling pathways activated by both BAFF and ARRIL in mammary gland point towards NF- $\mathrm{kB}$ activation which causes upregulation of bax. (Key Words : B Cell Activating Factor, APRIL, Apoptosis, Mammary Gland)
\end{abstract}

\section{INTRODUCTION}

After the lactation period, the mammary gland undergoes an extensive remodeling process that leads to the involution of epithelial structures (Walker et al., 1989; Strange et al., 1992). The involution phase of mammary gland development is characterized by epithelial cell death. The involution process occurs in two phases. During the first phase, accumulation of milk is associated with an engorgement of the gland, with a marked change in the pattern of gene expression and with massive apoptosis of epithelial cells (Walker et al., 1989; Strange et al., 1992; Marti et al., 1999). Accumulation of factors in the milk, the shape change of epithelial cells due to the engorgement, changes of hormone levels and loss of survival factor function are possible triggers of this initial phase of apoptosis (Topper and Freeman, 1980; Feng et al., 1995; Li

\footnotetext{
* Corresponding Author: M. G. Baik. Tel: +82-62-530-2164, Fax: +82-62-530-2169, E-mail: mgbaik@chonnam.ac.kr Received March 22, 2006; Accepted October 25, 2006
}

et al., 1997; Chapman et al., 1999; Marti et al., 1997, 1999). However, it remains still unclear how these changes are translated into an apoptotic response in milk producing mammary epithelial cells. During the second phase, extracellular matrix degrading proteases are produced that may be responsible for the collapse of lobulo-alveolar structures and the subsequent tissue remodeling (Talhouk et al., 1992; Lund et al., 1996; Li et al., 1997).

The induction of several genes including stromelysin, Fas antigen, Bok, interleukin-10, lysozyme, and interleukin$1 \beta$ converting enzyme has been reported during involution of the mammary gland and in apoptotic mammary epithelial HC11 cells (Boudreau et al., 1995; Ha et al., 2001; Lee et al., 2001; Kim et al., 2003). In previous study, we observed induction of extracellular proteinase inhibitor (Expi) gene in apoptotic mammary epithelial cells (Jung et al., 2004). The Expi, previously known as WDNM1 (Dear et al., 1988, 1989), is a member of the four-disulfide core family of proteins (Dear and Kefford, 1991), which include proteins that share a characteristic pattern of cystein residues 
Table 1. Primer information for RT-PCR analysis

\begin{tabular}{lllll}
\hline Gene & 5'-primer & 3'-primer & Size (bp) & Reference \\
\hline BAFF & ggaatggatgagtctgcaaagacc & ctccagcaagtgagttacagc & 948 & Schneider et al., 1999 \\
BAFF-R & actgtcccagctgcatgagg & agctgtcttggtggtcacca & 540 & Thompson et al., 2001 \\
APRIL & ggtccctagctcatgccagc & gttccatgcggagaaaggct & 710 & Yu et al., 2000 \\
NF- $\mathrm{kB}$ & gatgatccctacggaactgg & atacacgcctctgtcatccg & 470 & Ghosh et al., 1990 \\
Bcl-2 & tcgtgatgaagtacatacat & ggagaaatcaaacagaggtc & 580 & Negrini et al., 1987 \\
Bcl-xL & tggtcgacttctctcctac & gagatccacaaaagtgtccc & 557 & Gonzalez-Garcia et al., 1994 \\
Bax & acagggttcatcaggatc & acaaagatggtcactgtctg & 450 & Oltvai et al., 1993 \\
\hline
\end{tabular}

forming intrachain disulfide bonds involved in stabilizing protein structure. Our previous results show that the expression of Expi gene was induced during involution of mammary gland (Jung et al., 2004). Overexpression of Expi gene accelerated apoptosis of mammary epithelial cells, and induced expression of $B$ cell activating factor (BAFF).

BAFF is a recently identified member of the tumor necrosis factor (TNF) family of ligand. A proliferationinducing ligand (APRIL), another TNF family member, is the closest known relative of BAFF and is produced by macrophages (Hahne et al., 1998). APRIL is involved in the regulation of death ligand-induced apoptotic signaling in malignant glioma cells (Roth et al., 2001). Three BAFF receptors, B-cell maturation antigen (BCMA), transmembrane activator and CAML interactor (TACI) and BAFF-receptor (BAFF-R), have been known (Laabi et al., 2001). BAFF preferentially binds to BAFF-R and TACI and interacts with BCMA more weakly. Previously, only expression of the BAFF-R was detected and induced in the Expi-transfected cells, while the TACI and the BCMA expression was not detected in mammary epithelial cells (Jung et al., 2004). BAFF and APRIL also share two receptors, TACI and BCMA. But, APRIL binds more avidly to BCMA than to TACI and does not bind to BAFF-R. It has been suggested that APRIL receptor exists and expects it to be expressed on epithelial cells. BAFF and APRIL pathways and expression patterns of related genes have not been studies in mammary epithelial cells.

In other cell types, NF- $\kappa \mathrm{B}$ and bcl-2 family genes have been postulated to involve in BAFF and APRIL pathways. There is no report on BAFF and APRIL expression in the involution stage of mammary gland at which active apoptosis occurs in mammary epithelial cells. Purpose of this study was to examine expression patterns of BAFF and APRIL pathway-related genes including BAFF-R, NF- $\kappa$ B and bcl-2 family genes in the Expi-transfected HC11 cells and in various reproductive stages of mouse mammary gland.

\section{MATERIALS AND METHODS}

\section{Culture of Expi-transfected mammary epithelial HC11 cells}

In this study, previously developed cell lines overexpressing Expi gene were used (Jung et al., 2004). Briefly, Expi gene expression vector was constructed by ligating into $\mathrm{pBK}-\mathrm{CMV}$ vector, and the recombinant DNA was transfected into HC11 cells using lipofectamine method. After G418 selection, we isolated colonies of pExpi- and of pNeo-transfected cells. HC11 cells were cultured in RPMI1640 growth medium (Gibco BRL, USA) containing $10 \%$ fetal bovine serum (Gibco BRL), $5 \mu \mathrm{g} / \mathrm{ml}$ insulin, 10 $\eta \mathrm{g} / \mathrm{ml}$ epidermal growth factor (EGF), and $50 \mu \mathrm{g} / \mathrm{ml}$ gentamycin (Sigma, USA) in a $5 \% \mathrm{CO}_{2}$ at $37^{\circ} \mathrm{C}$ (Ball et al., 1988; Seol et al., 2006). Confluent cells were cultured in medium containing 2\% FBS and insulin for 2 days and incubated in serum-free medium without insulin and EGF for 2 days in order to induce apoptotic conditions.

\section{Tissue sampling and northern analysis}

The ICR mouse mammary membrane (Seegene, Korea), which is pre-made for immediate use, was analyzed for northern analyses of BAFF, BAFF-R, APRIL and NF- $\kappa$ B genes. Mouse mammary tissues were also prepared from pregnancy, lactation and involution stages for northern analysis of bcl-2, bcl-xL and bax genes. Since mice have relatively small amounts of tissues at involution 3,4 , and 7 days, mammary tissues were collected and pooled from four animals at each stage, and used for a northern analysis. Mammary tissues were pooled from three animals at pregnant day 12 , lactating day 6 , and involution days 1 and 2 for one experiment. For the induction of involution, the young were removed 10 days after parturition, and the mammary tissues were obtained at the indicated time after weaning.

Total RNA was extracted by the acid guanidinium thiocyanate phenol/chloroform method (Chomczynski and Sacchi, 1987). Twenty micrograms of total RNA were electrophoresed on a $1 \%$ agarose gel containing formaldehyde, and blotted onto a membrane. cDNAs of BAFF, BAFF-R, APRIL, NF- $\kappa \mathrm{B}, \mathrm{Bcl}-2, \mathrm{Bcl}-\mathrm{xL}$ and Bax genes were amplified by RT (reverse transcriptase)-PCR using total RNA templates isolated from mammary gland. Primer information was shown in Table 1 . PCR reaction was performed using Taq polymerase for 30 cycles at $55^{\circ} \mathrm{C}$ annealing temp. RT-PCR products were purified using AccuPrep ${ }^{\mathrm{TM}}$ PCR purification kit (Bioneer, Korea). Purified PCR products were cloned into TA cloning vector, pCR2.1 


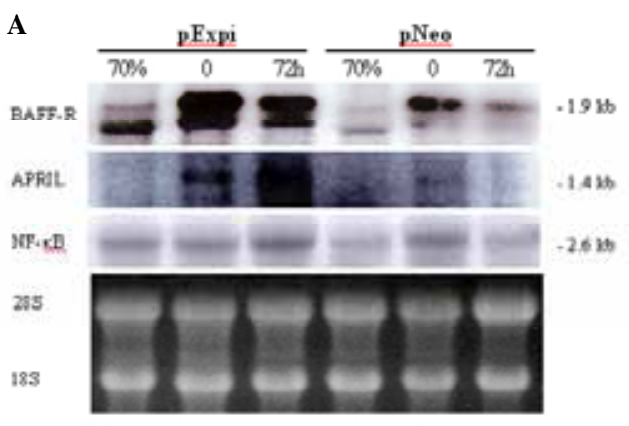

B
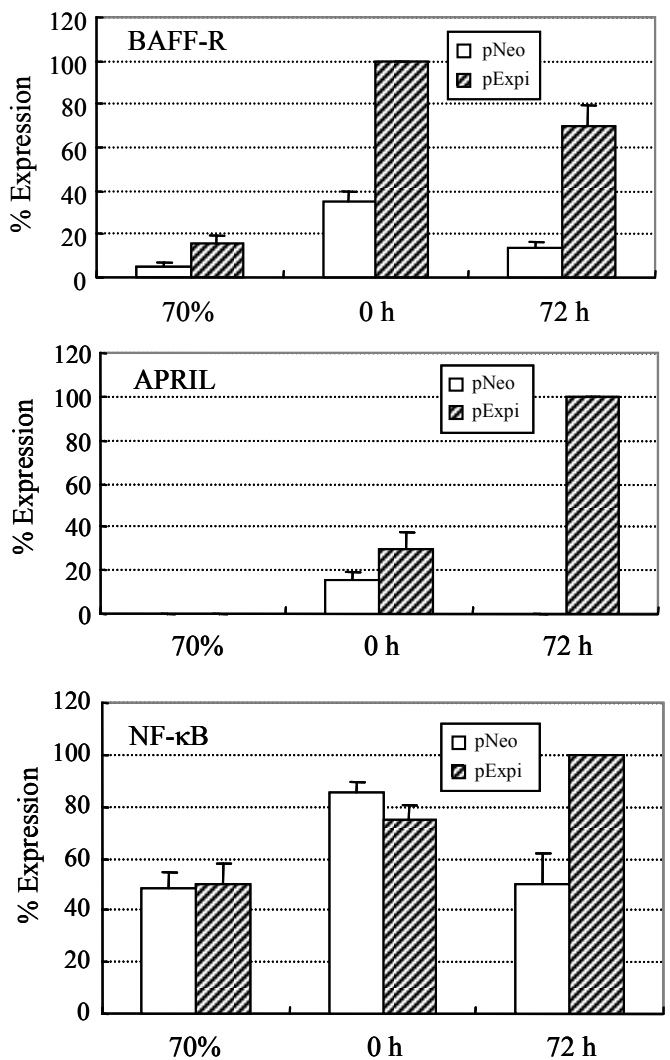

Figure 1. Expression of BAFF-R, APRIL and NF- $\kappa$ B genes in the Expi-transfected $\mathrm{HC} 11$ cells. (A) The pExpi and pNeo plasmids were transfected in $\mathrm{HC} 11$ cells, and stable cell lines overexpressing Expi gene were previously established (Jung et al., 2004). The cells were grown to confluency in growth medium containing EGF, insulin and 10\% FBS, kept for 2 days in the medium containing $2 \%$ FBS but neither insulin nor EGF. The cells were incubated for 0 and $72 \mathrm{~h}$ in serum-free medium, and total RNA was prepared from cells. The total RNA was also prepared from the $70 \%$ confluent cells cultured in growth media $(70 \%)$. mRNA levels were determined by northern analysis using ${ }^{32} \mathrm{P}$ labeled cDNA probe. The $28 \mathrm{~S}$ and $18 \mathrm{~S}$ rRNAs were shown as loading control. (B) mRNA levels were quantitated by phosphoimage analyzer. Values of percent expression (mRNA levels/28S) were normalized to 100 for the highest expression levels of each gene. Bars indicate standard deviation $(n=3)$.

(Invitrogen, USA), and correct nucleotide information was confirmed by nucleotide sequencing. The plasmid was digested with EcoR I, and the insert was obtained after low melting agarose gel electrophoresis. The insert of cDNA clone was labeled using a Prime-It Random Primer Labeling Kit (Stratagene). The membrane was hybridized with the ${ }^{32} \mathrm{P}$-labeled insert of the cDNA clone. The equal amount of RNA loading was confirmed by the intensities of $28 \mathrm{~S}$ and $18 \mathrm{~S}$ band, and the efficiency of transfer was monitored by ethidium bromide staining.

The membrane was prehybridized with the prehybridization solution (10\% dextran sulfate, $0.5 \%$ SDS, $6 \times \mathrm{SSC}, 1 \mathrm{mM}$ EDTA, $100 \mu \mathrm{g} / \mathrm{ml}$ salmon sperm DNA) at $65^{\circ} \mathrm{C}$ for $1 \mathrm{~h}$, and the cDNA probe preheated at $95^{\circ} \mathrm{C}$ was added, and hybridization was performed at $65^{\circ} \mathrm{C}$ for $20 \mathrm{~h}$. The membranes were washed twice in $2 \times \mathrm{SSC} / 0.1 \% \mathrm{SDS}$ at room temperature for $10 \mathrm{~min}$, once in $2 \times \mathrm{SSC} / 0.1 \% \mathrm{SDS}$ at $42^{\circ} \mathrm{C}$ for $30 \mathrm{~min}$, once in $0.1 \times \mathrm{SSC} / 0.1 \% \mathrm{SDS}$ at $42^{\circ} \mathrm{C}$ for $30 \mathrm{~min}$, and once in $0.1 \times \mathrm{SSC} / 0.1 \% \mathrm{SDS}$ at $55^{\circ} \mathrm{C}$ for $30 \mathrm{~min}$, and once in $0.1 \times \mathrm{SSC} / 0.1 \% \mathrm{SDS}$ at $68^{\circ} \mathrm{C}$ for $30 \mathrm{~min}$. The membranes were exposed to phosphoimage cassette at room temperature for 24-48 h.

\section{RESULTS AND DISCUSSION}

\section{Expression of BAFF-R, APRIL and NF- $\kappa$ B genes in Expi-transfected mammary epithelial cells}

The Expi is a member of the four-disulfide core family of proteins (Dear and Kefford, 1991). Previously, we found that the overexpression of Expi accelerated the apoptosis of mammary epithelial cells under serum starvation (Jung et al., 2004), and induction of B cell activating factor (BAFF) gene expression was observed in the Expi-overexpressed apoptotic cells. BAFF is a survival/maturation factor for peripheral $\mathrm{B}$ cells and this activity is mediated through a BAFF-specific receptor, BAFF-R. BAFF and APRIL are two related members of the TNF ligand superfamily (Mackay and Ambrose, 2003). APRIL plays a role in Tindependent type II antigen responses and T cell survival, but can also induce proliferation/survival of non-lymphoid cells. In the current study, expression levels of BAFF and APRIL pathway-related genes were examined by northern analysis in pExpi-transfected cells at $70 \%$ confluent stage and $0 \mathrm{~h}$ and $72 \mathrm{~h}$ incubation in serum-free media. Expitransfection showed a strong upregulation (3-5 folds) of BAFF-R gene expression at $70 \%$ confluent stage and at $0 \mathrm{~h}$ and $72 \mathrm{~h}$ in serum-free media (Figure 1). Expression of APRIL gene was not detected at $70 \%$ confluent stage in both Expi- and Neo-transfected cells. But, Expi-transfection showed 2 and 10 fold increase in APRIL gene expression at $0 \mathrm{~h}$ and $72 \mathrm{~h}$, respectively. Expi-transfection showed a slight

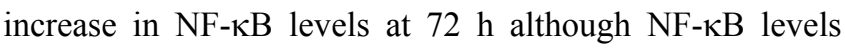
were similar at $70 \%$ confluent stage and at $0 \mathrm{~h}$ in Expi- and 


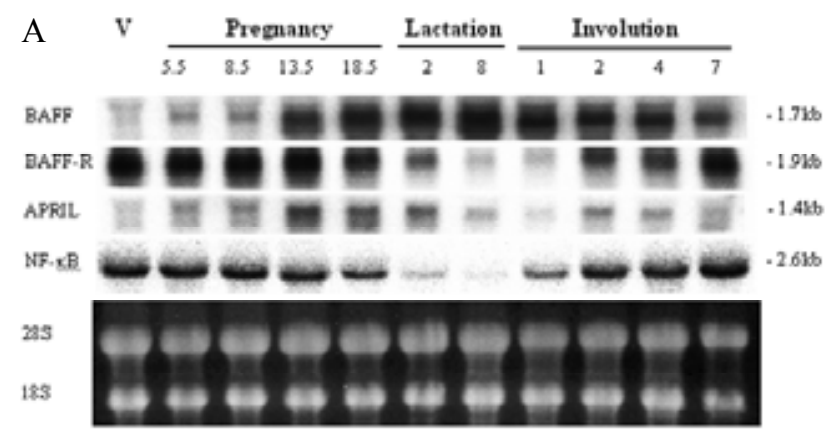

B
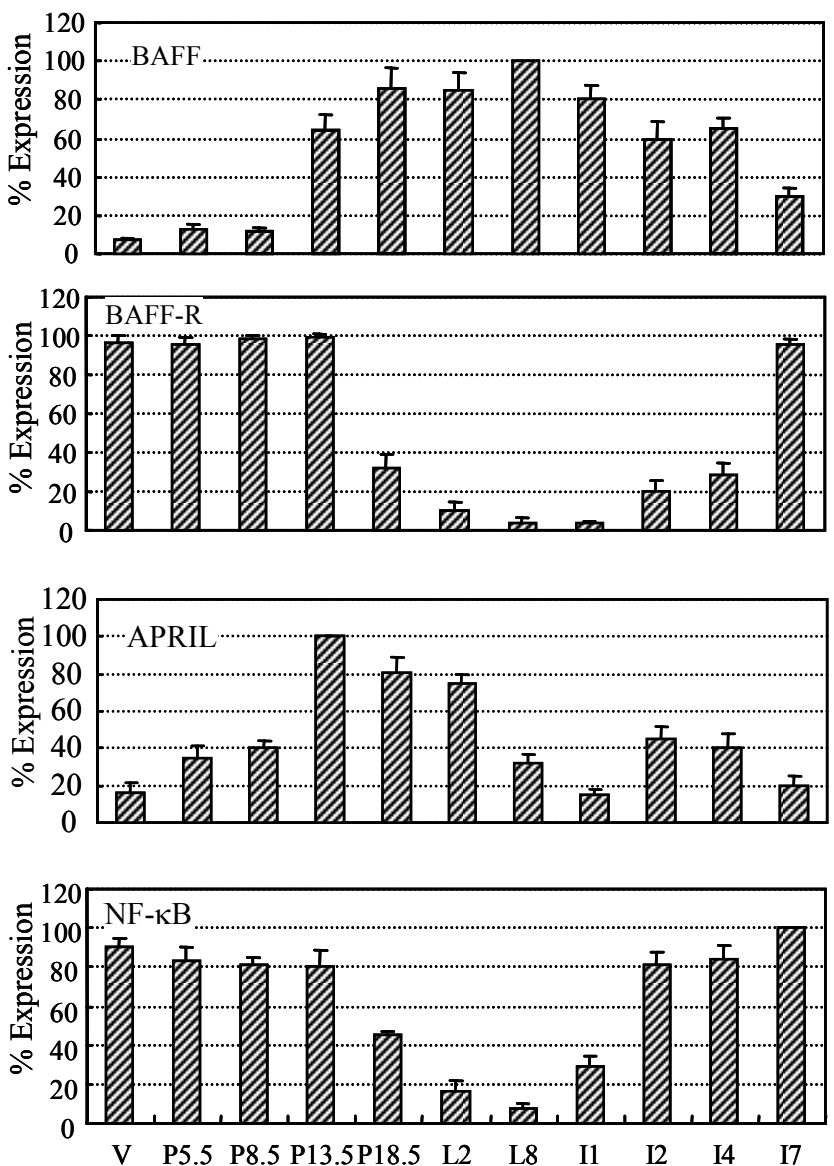

Figure 2. Northern analysis of BAFF and APRIL pathway-related genes in mouse mammary gland. (A) The total RNA blot prepared at virgin (V), pregnant 5.5, 8.5, 13.5, and 18.5 days (P5.5, P8.5, $\mathrm{P} 13.5, \mathrm{P} 18.5)$, lactation 2 and 8 days (L2, L8), and involution 1, 2 , 4 , and 7 days (I1, I2, I4, I7) in mouse mammary gland was hybridized with ${ }^{32} \mathrm{P}$-labeled cDNA probe. The $28 \mathrm{~S}$ and $18 \mathrm{~S}$ rRNAs were shown as loading control. (B) mRNA levels were quantitated by phosphoimage analyzer. Values of percent expression (mRNA levels/28S) were normalized to 100 for the highest expression levels of each gene. Bars indicate standard deviation $(n=3)$.

Neo-transfected cells. These suggest that BAFF and APRIL pathways may be involved in the apoptosis of mammary epithelial cells.

\section{Expression of BAFF pathway and Bcl-2 family genes in} mouse mammary gland

BAFF signals were mediated via BAFF-R, NF- $\mathrm{KB}$ and Bcl-2 family genes in B cells. BAFF signaling pathways have not been studied in mammary epithelial cells. Expression pattern of BAFF and APRIL pathway-related genes was examined in mouse mammary gland at various physiological stages including virgin, pregnancy $(5.5,8.5$, 13.5 and 18.5 days), lactation ( 2 and 8 days), and involution stages (1, 2, 4, and 7 days). Expression levels of BAFF gene were very low at early pregnancy (5.5 and 8.5 days of pregnancy), increased from mid-pregnancy (13.5 days of pregnancy), and peaked at lactation, and expression levels were slightly decreased at involution stages of mammary gland (Figure 2). Thus, BAFF transcripts seem to be abundant from late pregnancy through lactation and involution stages, and expression patterns of BAFF gene are not correlated to apoptotic status of mammary gland: active apoptosis of mammary epithelial cells occurs at involution stage of mammary gland. Expression levels of BAFFreceptor (BAFF-R) gene were relatively high at virgin through mid pregnancy, the expression was decreased at lactation stages, then the expression was highly induced from involution day 2 and high levels were maintained until involution days 7. Results suggest that expression patterns of BAFF-R are more correlated with apoptosis of mammary epithelial cells than BAFF molecules itself. Expression levels of APRIL gene were low at virgin and early pregnancy, increased at mid- and late-pregnancy, and then decreased during lactation and slightly increased during involution. Further study is required to understand functional role of BAFF pathway in mammary gland.

The NF- $\mathrm{BB}$ pathways were used by the receptors for BAFF and APRIL in B cells. BAFF-induced BAFF-R signaling is primarily mediated via the alternative NF- $\kappa B$ pathway. This pathway leads to cleavage of $\mathrm{p} 100$ to $\mathrm{p} 52$ (NF-kB-2). A dimer of $\mathrm{p} 52$ and RelB is translocated into the nucleus where it activates target gene transcription. BAFF may also activate the classical NF- $\kappa B$ pathway. We also examined expression of NF-kB gene in mammary gland. Expression patterns of NF- $\mathrm{kB}$ gene were similar as those of BAFF-R: high levels were maintained from virgin through mid-pregnancy, the levels decreased sharply at lactation and increased from involution day 2, and high levels were maintained until involution days 7.

The NF-kB family of transcription factors has been implicated in such diverse cellular processes as proliferation, differentiation, and apoptosis. Generally, the NF- $\mathrm{BB}$ activation delivers a survival signal (Beg and Baltimore, 1996; Van Antwerp et al., 1996) by promoting the expression of survival factors, such as some members of the inhibitor of apoptosis (IAP) family (c-IAP1, c-IAP2, and XIAP) (Rayet and Gelinas, 1999) and bcl-xL (Visconti, 


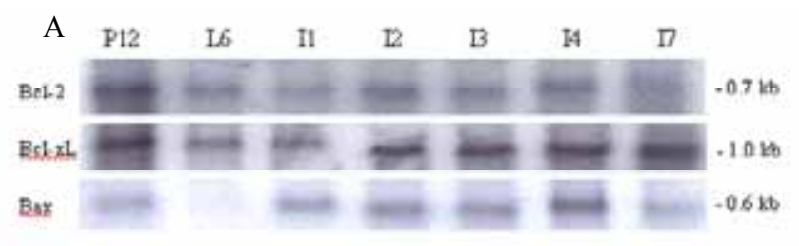

B
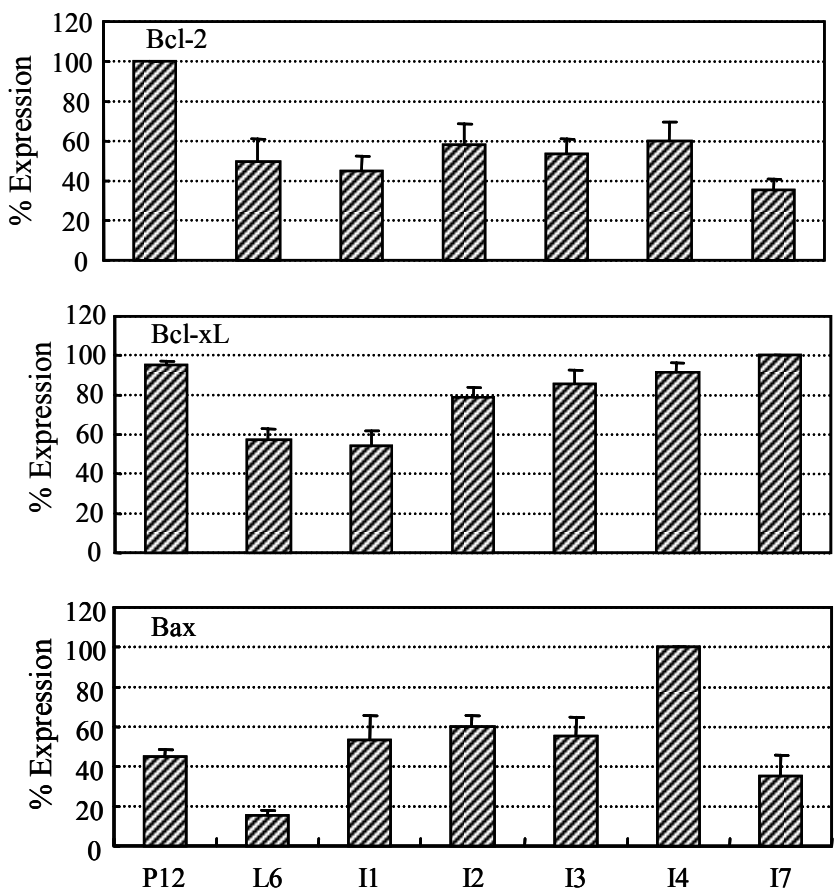

Figure 3. mRNA levels of bcl-2 family members in mouse mammary gland. (A) The total RNA was prepared at pregnant 12 days (P12), lactation 6 days (L6) and involution 1, 2, 3, 4, and 7 days (I1, I2, I3, I4, I7) of mammary gland, and northern analysis was performed using ${ }^{32} \mathrm{P}$-labeled cDNA probe. (B) mRNA levels were quantitated by phosphoimage analyzer. Values of percent expression (mRNA levels/28S) were normalized to 100 for the highest expression levels of each gene. Bars indicate standard deviation $(\mathrm{n}=3)$.

1997). In contrast, current study shows induction of NF-kB gene expression during involution of mammary gland at which stage active cell death occurs in mammary epithelial cells. Clarkson et al. (2000) also described the activation of $\mathrm{NF}-\mathrm{kB}$ during involution of the mouse mammary gland. But, active NF-KB localized exclusively to nonapoptotic epithelial cells both in vivo and in the mammary epithelial cell line, KIM-2 (Clarkson et al., 2000). They have suggested that NF- $\mathrm{KB}$ might have a selective survival function in epithelial cells.

There are also reports about a pro-apoptotic role for NF$\kappa B$ (Kim et al., 2006). Several NF- $\kappa B$ stimulators such as TNF (Barger et al., 1995), ceramide (Hunot et al., 1997), $\mathrm{H} 2 \mathrm{O} 2$, and serum deprivation (Grimm et al., 1996) ultimately induce apoptosis. The NF-kB-induced death receptor 4 (DR4), DR5 (Ravi et al., 2001), TNF-related apoptosis-inducing ligand (TRAIL) (Rivera-Walsh et al., 2001), Fas (Zheng et al., 2001), and Fas ligand (FasL) (Lin et al., 1999) all may promote cell death. The upstream promoter regions of several death genes contain potential NF- $\mathrm{KB}$ binding motifs (Grimm et al., 1996). These conflicting studies of the role of NF- $\mathrm{KB}$ in apoptosis suggest that the effects of many signaling molecules are dependent upon cell content and/or stress.

We analyzed mRNA levels of bcl-2 family member bcl2, bcl-xL and bax genes. Pro-apoptotic bax mRNA levels were upregulated at the onset of involution, with a highest increase in expression occurring at the lactation to involution transition (Figure 3). Previous studies also showed induction of bax gene expression during involution of mouse mammary gland (Metcalfe et al., 1999; Walton et al., 2001). Expression of death-suppressors bcl-2 and bcl-xL was examined in mammary gland. Bcl-2 expression was downregulated during lactation and involution compared to pregnancy, and bcl-2 levels were constant during lactation and involution. Previously, transcripts of bcl-2 gene were not detected at any developmental stages of mammary gland (Walton et al., 2001). Other study showed that expression of bcl-2 gene was low and similar during lactation and early involution, while expression increased during late involution (Schorr et al., 1999). Bcl-xL levels were decreased during lactation compared to pregnancy, and there was a slight increase in bcl-xL levels during involution compared to lactation.

In summary, our results suggest that signaling pathways activated by both BAFF and ARRIL in mammary gland point towards NF- $\mathrm{kB}$ activation which causes upregulation of bax. A further study is needed to test whether BAFF and $\mathrm{NF}-\mathrm{\kappa B}$ molecules have significant roles in either proliferation or apoptosis of mammary epithelial cells during involution of mammary gland.

\section{ACKNOWLEDGMENTS}

This study was financially supported by Korea Research Foundation Grant (KRF-2003-015-C00649). This work was supported by the Brain Korea 21 Project in 2006.

\section{REFERENCES}

Ball, R. K., R. R. Friis, C.-A. Schonenberger, W. Doppler and B. Groner. 1994. Prolactin regulation of $\beta$-casein gene expression and of a cytosolic $120-\mathrm{kd}$ protein in a cloned mouse mammary epithelial cell line. EMBO J. 7:2089-2095.

Barger, S. W., D. Horster, K. Furukawa, Y. Goddman, J. Krieglestein and M. P. Mattson. 1995. Tumor necrosis factors alpha and beta protect neurons against amyloid beta-peptide toxicity: evidence for involvement of a kappa B-binding factor and attenuation of peroxide and $\mathrm{Ca}^{2+}$ accumulation. Proc. Natl. Acad. Sci. USA 92:9328-9332. 
Beg, A. A. and D. Baltimore. 1996. An essential role for NFkappaB in preventing TNF-alpha-induced cell death. Sci. 274:782-784.

Boudreau, N., C. J. Sympson, Z. Werb and M. J. Bissell. 1995. Suppression of ICE and apoptosis in mammary epithelial cells by extracellular matrix. Sci. 267:891-893.

Chapman, R. S., P. C. Lourenco, E. Tonner, D. J. Flint, S. Selbert, K. Takeda, S. Akira, A. R. Clarke and C. J. Watson. 1999. Suppression of epithelial apoptosis and delayed mammary gland involution in mice with a conditional knockout of Stat3. Genes Dev. 13:2604-2616.

Chomozynski, P. and N. Sacchi. 1987. Single-step method of RNA isolation by acid guanidinium thiocyanate-phenol-chloroform extraction. Anal. Biochem. 162:156-159.

Clarkson, R. W., J. L. Heeley, R. Chapman, F. Aillet, R. T. Hay, A. Wyllie and C. J. Watson. 2000. NF-kappaB inhibits apoptosis in murine mammary epithelia. J. Biol. Chem. 275:1273712742.

Dear, T. N., I. A. Ramshaw and R. F. Kefford. 1988. Differential expression of a novel gene, WDNM1, in nonmetastatic rat mammary adenocarcinoma cells. Cancer Res. 48:5203-5209.

Dear, T. N., D. A. McDonald and R. F. Kefford. 1989. Transcriptional down-regulation of a gene, WDNM2, in metastatic DMBA-8 cells. Cancer Res. 49:5323-5328.

Dear, T. N. and R. F. Kefford. 1991. The WDNM1 gene product is a novel member of the 'four-disulphide core' family of proteins. Biochem. Biophys. Res. Comm. 176:247-254.

Feng, Z., A. Marti, B. Jehn, H. J. Altermatt, G. Chicaiza and R. Jaggi. 1995. Glucocorticoid and progesterone inhibit involution and programmed cell death in the mouse mammary gland. J. Cell Biol. 131:1095-1103.

Ghosh, S., A. M. Gifford, L. R. Riviere, P. Tempst, G. P. Nolan and D. Baltimore. 1990. Cloning of the p50 DNA binding subunit of NF-kB: homology to rel and dorsal. Cell 62:1019-1029.

Gonzalez-Garcia, M., R. Perez-Ballestero, L. Ding, L. Duan, L. H. Boise, C. B. Thompson and G. Nunez. 1994. Bcl-xL is the major Bcl-x mRNA form expressed during murine development and its product localizes to mitochondria. Development 120:3033-3042.

Grimm, S., M. K. Bauer, P. A. Baeuerle and K. Schulze-Osthoff. 1996. Bcl-2 down-regulates the activity of transcription factor NF-kappaB induced upon apoptosis. J. Cell Biol. 134:13-23.

Ha, S. H., S. R. Lee, T. H. Lee, Y. M. Kim, M. Baik and Y. J. Choi. 2001. The expression of Bok is regulated by serum in HC11 mammary epithelial cells. Mol. Cells 12:368-371.

Hahne, M., T. Kataoka, M. Schröter, K. Hofmann, M. Irmler, J.- L. Bodmer, P. Schneider, T. Bornand, N. Holler, L. E. French, B. Sordat, D. Rimoldi and J. Tschopp. 1998. APRIL, a new ligand of the tumor necrosis factor family, stimulates tumor cell growth. J. Exp. Med. 188:1185-1190.

Hunot, S., B. Brugg, D. Ricard, P. P. Michel, M. P. Muriel, M. Ruberg, B. A. Faucheux, Y. Agid and E. C. Hirsch. 1997. Nuclear translocation of NF-kappaB is increased in dopaminergic neurons of patients with parkinson disease. Proc. Natl. Acad. Sci. USA 94:7531-7536.

Jung, D. J., J. J. Bong and M. Baik. 2004. Extracellular proteinase inhibitor-accelerated apoptosis is associated with B cell activating factor in mammary epithelial cells. Exp. Cell Res.
292:115-122.

Kim, T. W., H. B. Moon and S. J. Kim. 2003. Interleukin-10 is upregulated by prolactin and serum-starvation in cultured mammary epithelial cells. Mol. Cells 16:168-172.

Kim, S. B., J. S. Kim, J. H. Lee, W. J. Yoon, D. S. Lee, M. S. Ko, B. S. Kwon, D. H. Choi, H. R. Cho, B. J. Lee, D. K. Chung, H. W. Lee and J. W. Park. 2006. NF-kappaB activation is required for cisplatin-induced apoptosis in head and neck squamous carcinoma cells. FEBS Lett. 580:311-318.

Laabi, Y., A. Egle and A. Strasser. 2001. TNF cytokine family: more BAFF-ling complexities. Current Biol. 11:R1013-1016.

Lee, M. J., O. Han, K. Back, Y. J. Choi and M. G. Baik. 2001. Induction of lysozyme gene expression during involution of mouse mammary gland. Asian-Aust. J. Anim. Sci. 14:462-466.

Li, M., X. Liu, G. Robinson, U. Bar-Peled, K. U. Wagner, W. S. Young, L. Hennighausen and P. A. Furth. 1997. Mammaryderived signals activated programmed cell death during the first stage of mammary gland involution. Proc. Natl. Acad. Sci. 94:3425-3430.

Lin, B., C. Williams-Skipp, Y. Tao, M. S. Schleicher, L. L. Cano, R. C. Duke and R. Scheinman. 1999. NF-kappaB functions as both a proapoptotic and antiapoptotic regulatory factor within a single cell type. Cell Death Differ. 6:570-582.

Lund, L. R., J. Romer, N. Thomasset, H. Solberg, C. Pyke, M. J. Bissell, K. Dano and Z. Werb. 1996. Two distinct phases of apoptosis in mammary gland involution: proteinaseindependent and dependent pathways. Development 122:181193.

Mackay, F. and C. Ambrose. 2003. The TNF family members BAFF and APRIL: the growing complexity. Cytokine and Growth Factor Reviews 14:311-324.

Metcalfe, A. D., A. Gilmore, T. Klinowska, J. Oliver, A. J. Valentijn, R. Brown, A. Ross, G. MacGregor, J. A. Hickman and C. H. Streuli. 1999. Developmental regulation of Bcl-2 family protein expression in the involuting mammary gland. J. Cell Sci. 112(Pt 11):1771-1783.

Marti, A., Z. Feng, H. J. Altermatt and R. Jaggi. 1997. Milk accumulation triggers apoptosis of mammary epithelial cells. Eur. J. Cell Biol. 73:158-165.

Marti, A., H. Lazar, P. Ritter and R. Jaggi. 1999. Transcription factor activities and gene expression during mouse mammary gland involution. J. Mammary Gland Biol. Neoplasia 4:145152.

Negrini, M., E. Silini, C. Kozak, Y. Tsujimoto and C. M. Croce. 1987. Molecular analysis of mbcl-2: structure and expression of the murine gene homologous to the human gene involved in follicular lymphoma. Cell 49:455-463.

Oltvai, Z. N., C. L. Milliman and S. J. Korsmeyer. 1993. Bcl-2 heterodimerizes in vivo with a conserved homolog, Bax, that accelerates programmed cell death. Cell 74:609-619.

Ravi, R., G. C. Bedi, L. W. Engstrom, Q. Zeng, B. Mookerjee, C. Gelinas, E. J. Fuchs and A. Bedi. 2001. Regulation of death receptor expression and TRAIL/Apo2L-induced apoptosis by NF-kappaB. Nat. Cell Biol. 3:409-416.

Rayet, B. and C. Gelinas. 1999. Aberrant rel/nfkb genes and activity in human cancer. Oncogene 18:6938-6947.

Rivera-Walsh, I., M. Waterfield, G. Xiao, A. Fong and S. C. Sun. 2001. NF-kappaB signaling pathway governs TRAIL gene 
expression and human T-cell leukemia virus-I Tax-induced Tcell death. J. Biol. Chem. 276:40385-40388.

Roth, W., B. Wagenknecht, A. Klumpp, U. Naumann, M. Hahne, J. Tschopp and M. Weller. 2001. APRIL, a new member of the tumor necrosis factor family, modulates death ligand-induced apoptosis. Cell Death Differ. 8:403-410.

Schneider, P., F. MacKay, V. Steiner, K. Hofmann, J. L. Bodmer, N. Holler, C. Ambrose, P. Lawton, S. Bixler, H. Acha-Orbea, D. Valmori, P. Romero, C. Werner-Favre, R. H. Zubler, J. L. Browning and J. Tschopp. 1999. BAFF, a novel ligand of the tumor necrosis factor family, stimulates B cell growth, J. Exp. Med. 189:1747-1756.

Schorr, K., M. Li, S. Krajewski, J. C. Reed and P. A. Furth. 1999. $\mathrm{Bcl}-2$ gene family and related proteins in mammary gland involution and breast cancer. J. Mammary Gland Biol. Neoplasia 4:153-164.

Seol, M. B., J. J. Bong and M. Baik. 2006. Involvement of cathepsin D in apoptosis of mammary epithelial cells. AsianAust. J. Anim. Sci. 19:1100-1105.

Strange, R., F. Li, S. Saurer, A. Burkhardt and R. R. Friis. 1992. Apoptotic cell death and tissue remodelling during mouse mammary gland involution. Development 115:49-58.

Talhouk, R. S., M. J. Bissell and Z. Werb. 1992. Coordinated expression of extracellular matrix-degrading proteinases and their inhibitors regulates mammary epithelial function during involution. J. Cell Biol. 118:1271-1282.

Thompson, J. S., S. A. Bixler, F. Qian, K. Vora, M. L. Scott, T. G. Cachero, C. Hession, P. Schneider, I. D. Sizing, C. Mullen, P. Strauch, M. Zafari, C. D. Benjamin, J. Tschopp, J. L. Browning and C. Ambrose. 2001. BAFF-R, a newly identified TNF receptor that specifically interacts with BAFF. Sci. 293:2108-2111.
Topper, Y. J. and C. S. Freeman. 1980. Multiple hormone interactions in the developmental biology of the mammary gland. Physiol. Rev. 60:1049-1106.

Van Antwerp, D. J., S. J. Martin, T. Kafri, D. R. Green and I. M. Verma. 1996. Suppression of TNF-alpha-induced apoptosis by NF-kappaB. Sci. 274:787-789.

Visconti, R., J. Cerutti, S. Battista, M. Fedele, F. Trapasso, K. Zeki, M. P. Miano, F. de Nigris, L. Casalino, F. Curcio, M. Santoro and A. Fusco. 1997. Expression of the neoplastic phenotype by human thyroid carcinoma cell lines requires NFkappaB p65 protein expression. Oncogene 15:1987-1994.

Walker, N. I., R. E. Bennett and J. F. Kerr. 1989. Cell death by apoptosis during involution of the lactating breast in mice and rats. Am. J. Anat. 185:19-32.

Walton, K. D., K. U. Wagner, E. B. Rucker. 3rd, J. M. Shillingford, K. Miyoshi and L. Hennighausen. 2001. Conditional deletion of the bcl-x gene from mouse mammary epithelium results in accelerated apoptosis during involution but does not compromise cell function during lactation. Mech. Dev. 109:281-293

Yu, G., T. Boone, J. Delaney, N. Hawkins, M. Kelley, M. Ramakrishnan, S. McCabe, J. Qiu, M. Kornuc, X.-Z. Xia, J. Guo, M. Stolina, W. J. Boyle, I. Sarosi, H. Hsu, G. Senaldi and L. E. Theill. 2000. APRIL and TALL-I and receptors BCMA and TACI: system for regulating humoral immunity. Nat. Immunol. 1:252-256.

Zheng, Y., F. Ouaaz, P. Bruzzo, V. Singh, S. Gerondakis and A. A. Beg. 2001. NF-kappa B RelA (p65) is essential for TNFalphainduced fas expression but dispensable for both TCR induced expression and activation-induced cell death. J. Immunol. 166:4949-4957. 